\title{
Dietary intake in 6-year-old children from southern Poland: part 2 - vitamin and mineral intakes
}

\author{
Sylwia Merkiel ${ }^{*}$ and Wojciech Chalcarz
}

\begin{abstract}
Background: Studies on vitamin and mineral intakes in children are very important: firstly because of the high prevalence of diet-related diseases and secondly because of the widespread consumption of highly processed foods which are characterised by high energy content and low density of essential nutrients. Therefore, the purpose of this study was to analyse vitamin and mineral intakes in 6-year-old children from southern Poland.

Methods: Vitamin and mineral intakes were estimated from a three-day food record in 120 children, 64 girls and 56 boys, aged 6 years. Nutrient densities were estimated as amounts per $1000 \mathrm{kcal}(4185 \mathrm{~kJ})$ of energy intake. Statistical analysis was carried out by means of the IBM SPSS Statistics computer programme, version 19 . The studied population was divided according to gender.

Results: Intakes of folic acid ( $\mu \mathrm{g} / 1000 \mathrm{kcal})$ and vitamin C (mg, mg/1000 kcal) were significantly higher in girls. Nutrient densities for all vitamins were higher in girls, however, these results did not reach statistical significance. Intake of vitamin D was lower than EAR in all of the studied children. Intakes of sodium (mg) and zinc (mg) were significantly higher in boys. Intakes of the remaining minerals were higher in boys, however, these findings did not reach statistical significance. Nutrient densities for all minerals, except for sodium, zinc and manganese, were higher in girls. All of the studied children had sodium intakes above UL.

Conclusions: Inadequate intakes of vitamin D, calcium and potassium in the studied 6-year-olds along with excessive sodium intake are the risk factors for developing osteoporosis and hypertension. To prevent these diseases in the studied children, educational programmes for both preschool staff and parents should be worked out and implemented.
\end{abstract}

Keywords: Children, Dietary intake, Vitamins, Minerals, Nutrition, Diet

\section{Background}

In recent years, children's diets in the developed countries, although high in energy, protein, fat and simple carbohydrates, are usually characterised by low vitamin and mineral content. Studies on school children showed that this is largely due to an increased consumption of fast foods, salty snacks, candy and soft drinks along with lower intakes of fruit, vegetables, grains and milk [1]. A study in 1.5-4.5-yearold children showed a decreasing intake of most micronutrients with increasing intake of non-milk extrinsic sugars [2]. It was reported to be especially disturbing in the case of iron

\footnotetext{
* Correspondence: sylwiamerkiel@awf.poznan.pl
Food and Nutrition Department of the Eugeniusz Piasecki University School

*Correspondence: sylwiamerkiel@awf.poznan.pl
Food and Nutrition Department of the Eugeniusz Piasecki University School of Physical Education in Poznan, Poland Królowej Jadwigi 27/39 Street, 61-871 Poznan, Poland
}

and zinc which intakes fell below the Estimated Average Requirement in children who exceeded $24 \%$ of energy from non-milk extrinsic sugars [2]. Another study in German 2-18-year-olds showed a strong inverse association between vitamin and mineral intakes and intake of added sugars [3]. The authors [3] also reported that intakes of the following food groups: 'meat, fish and eggs', 'fats and oils', 'grain' and 'fruits and vegetables' fell with increasing intake of added sugars, with the strongest effect for 'fruits and vegetables'. In Norwegian children and adolescents, intakes of almost all micronutrients and intakes of fruit and vegetables decreased with increasing content of added sugar [4]. Also in American preschoolers, intakes of micronutrients, as well as grains, vegetables, fruits, and dairy decreased with increasing added sugar intake [5]. 
The observed trends are highly unfavourable, since vitamins and minerals are essential nutrients for healthy growth and proper development of children. Adequate intakes of these micronutrients play also an important role in the prevention of diet-related diseases. Preventing these diseases should start as early as in childhood [6]. Since vitamins and minerals are biologically active, both their deficiency and excess have unfavourable influence on human health, especially in childhood when providing adequate vitamin and mineral intakes is crucial for the child's physical, motor, mental and emotional development. It is particularly important for 6-year-old children who should attain school readiness [6] because in Poland and some European countries the age of six years is the last year of preschool attendance [7]. However, now in Poland, due to the changes in law, more and more children start school at the age of six years, similar to many European countries. Therefore, adequate intakes of vitamins and minerals are indispensable for the children to perform well at school. The studies showed that iodine, iron and folate are key nutrients for cognitive development $[8,9]$ and that other vitamins and minerals such as vitamin $\mathrm{B}_{12}$ or zinc may also be important [8].

After the year 2000, no publications on vitamin and mineral intakes of only 6-year-old children were found. However, nine studies published in eleven articles [10-19] reported intakes of selected micronutrients in populations of wide age ranges including 6-year-olds. All of these studies varied in terms of the age range of the studied children and the number of vitamins and minerals which were analysed. In the Polish national study on a representative sample [19] and in the British population study called the National Diet and Nutrition Survey of young people aged 4-18 years [13], intakes of as many as eighteen micronutrients in a subgroup of 4-6-year-old children were reported. Another British population study called the National Diet and Nutrition Survey Rolling Programme 2008/2009 2011/2012 [10] reported the intakes of even more micronutrients, nineteen, but in a subgroup of a wider age range, that is from 4 to 10 years. Intakes of eleven micronutrients were presented for a representative sample of Belgian preschoolers including a subgroup of 4-6.5-year-old children [14]. Intakes of vitamins and minerals in groups of children of quite a narrow age ranges are available for Spanish 6-7year-old children with intakes of nine micronutrients reported $[15,16]$ and for Cretan children aged 5.7-7.6 years with intakes of thirteen micronutrients reported [18]. However, in the latter study, intakes of vitamins and minerals were expressed as nutrient density only. Another study on Spanish children reported intakes of sixteen micronutrients in a subgroup of 6-9-year-old children [17]. Even wider age range was applied in the National Health and Nutrition Examination Survey, 1999-2000, which reported intakes of eighteen micronutrients in the United States population, including a subgroup of 6-11-year-old children [11,12].
Taking into account the high prevalence of diet-related diseases and the widespread consumption of highly processed foods which are characterised by high energy content along with low density of essential nutrients, it is especially important to investigate vitamin and mineral intakes in children. Therefore, the purpose of this study was to analyse vitamin and mineral intakes in 6-year-old children from southern Poland, including nutrient density.

\section{Methods \\ Subjects}

The studied population comprised 120 children, 64 girls and 56 boys, who attended the last grade in the preschools associated with the Nowy Sacz League of Preschools and Schools Promoting Health in Nowy Sacz and the vicinity. The sampling design has been described in detail previously [7]. The study was approved by the Bioethics Committee of the Poznan University of Medical Sciences.

\section{Vitamin and mineral intakes Data collection}

To assess vitamin and mineral intakes in the studied children, parents and preschool staff were asked to keep a food record for three days: two preschool days and one free day (Sunday). Intakes of vitamin and mineral supplements were also taken into account. All the details about the method were described in the previous part of this article [7].

\section{Dietary assessment}

Vitamin and mineral intakes were calculated using the Dieta 4.0 computer programme which contains food composition database. The programme estimates the changes of nutritional value by calculating the losses of nutrients resulting from food processing. This programme has been described in details in the previous articles $[7,20]$.

\section{Comparison with dietary reference intakes}

Vitamin and mineral intakes of the studied 6-year-olds were compared to dietary reference intakes for Polish population [21]. Intakes of vitamin $A, B_{1}, B_{2}, B_{6}$, folic acid, vitamin $B_{12}$, niacin, vitamin $C$, calcium, phosphorus, magnesium, iron, zinc, copper and iodine were compared to Estimated Average Requirement (EAR) [21]. Intakes of vitamin E, sodium and potassium were compared to Adequate Intake (AI) [21]. Dietary reference intakes for Polish population do not include EAR for vitamin D, thus intake of this vitamin was compared to EAR worked out by the Food and Nutrition Board of the Institute of Medicine [22]. Polish dietary reference intakes do not also include manganese, therefore intake of this mineral was compared to AI worked out by the Food and Nutrition Board of the Institute of Medicine [23].

Moreover, vitamin and mineral intakes of the studied children were compared to Tolerable Upper Intake Level 
(UL) when available. Sodium intake was compared to UL proposed by the National Food and Nutrition Institute in Warsaw [21]. Intakes of retinol, vitamin D, E, $\mathrm{B}_{6}$, folic acid, zinc, copper and iodine were compared to UL worked out by the Scientific Committee on Food [24] and intakes of niacin, vitamin $\mathrm{C}$, calcium, phosphorus, iron and manganese - to UL worked out by the Food and Nutrition Board of the Institute of Medicine [22,23,25-27]. Magnesium intake was not compared to UL. This is because the UL was established for magnesium from nonfood sources and the studied children did not take magnesium supplements. Nutrient densities were estimated as amounts per $1000 \mathrm{kcal}(4185 \mathrm{~kJ})$ of energy intake.

\section{Statistical analysis}

Statistical analysis was carried out by means of the IBM SPSS Statistics computer programme, version 19 (Chicago, IL, USA). The studied population was divided according to gender. Means, standard deviations (SD), medians and standard errors (SE) were calculated for vitamin and mineral intakes. The percentages of children with vitamin and mineral intakes below EAR were calculated to investigate the prevalence of inadequate intake. In addition, the percentages of children with vitamin and mineral intakes above UL were calculated to assess the risk of adverse health effects from excessive intake [28]. The percentages of children with nutrient intakes below AI were also presented, similarly to previous studies [14], however, it should be emphasised that AI cannot be used to estimate the prevalence of inadequate nutrient intakes for groups [28].

The same statistical methods as in the first part of the article were applied [7]. In the case of the qualitative variables, statistical significance was determined using Pearson's chisquare test. For testing normality of the quantitative variables, the Shapiro-Wilk statistic was used. For normally distributed variables, the unpaired Student's $t$ test was applied to investigate statistically significant differences, whereas for skewed variables - the non-parametric Mann-Whitney $U$ test was used. The level of significance in the case of all the tests was set at $P \leq 0.05$.

\section{Results}

Socio-demographic characteristics of the studied children and their families were presented in the previous article [7]. Table 1 shows vitamin intakes in the studied 6-yearold children and Table 2 presents the percentages of the studied 6-year-olds in the reference ranges for vitamin intakes. Intakes of folic acid $(\mu \mathrm{g} / 1000 \mathrm{kcal})$ and vitamin $\mathrm{C}$ $(\mathrm{mg}, \mathrm{mg} / 1000 \mathrm{kcal})$ were significantly higher in girls. It is important to mention that nutrient densities for all vitamins were higher in girls, however, these results did not reach statistical significance. It is also noteworthy that intake of vitamin D was lower than EAR in all of the studied children.

Table 3 presents mineral intakes in the studied 6-yearold children and Table 4 shows the percentages of the studied 6-year-olds in the reference ranges for mineral intakes. Intakes of sodium ( $\mathrm{mg}$ ) and zinc ( $\mathrm{mg}$ ) were significantly higher in boys. Also, intakes of the remaining minerals were higher in boys, however, these findings did not reach statistical significance. Although statistically insignificant, it is important to mention that nutrient densities for all minerals, except for sodium, zinc and manganese, were higher in girls. Moreover, all of the studied children had sodium intakes above UL and substantial percentage of them had intake of manganese above UL. Substantial percentages of the studied 6-yearolds had intake of calcium below EAR and intake of potassium below AI.

\section{Discussion}

\section{Methodological remarks}

To assess vitamin and mineral intakes in the studied 6year-olds, we chose an estimated food record. This method has the advantage of eliminating the problem of forgetting and improves estimation of portion size because the information is recorded at consumption [29]. Since food record carries a higher respondent burden [29], we chose a three-day period. Moreover, this method was most frequently used in the previous studies on vitamin and mineral intakes in children $[14,18,30]$. The methods used in other studies included a four-day estimated food record [10], a seven-day weighed food record [13], food frequency questionnaire $[15,16]$, one 24-hour dietary recall $[11,12,19]$ or a combination of 24-hour dietary recall and food frequency questionnaire [17]. The differences in vitamin and mineral intakes observed in the studied 6-yearolds and in the previously studied children [10-19] are surely caused by methodological differences. However, most probably various food habits explain most of these differences. For example, vitamin D intake was very low in all of the previously studied children $[10,14,15,17,30]$ irrespective of the method of dietary assessment and intake of vitamin A was much higher in Polish children, both in the studied 6-year-olds and in the previously studied 4-6-yearolds [19], in comparison to children from other countries, which may be explained by Polish food habits.

\section{Vitamin intakes}

Mean intakes of all the analysed vitamins, except for vitamin $\mathrm{D}$, were well above the reference values which implies low risk of inadequate intakes in the studied 6-year-old children. It is particularly favourable in the case of vitamins $B_{1}, B_{2}, B_{6}, B_{12}$ and folic acid. This is because inadequate intakes of these vitamins are linked to elevated plasma homocysteine concentration which, in turn, is related to 
Table 1 Vitamin intakes in the studied 6-year-old children

\begin{tabular}{|c|c|c|c|c|c|c|c|c|c|c|c|c|c|c|}
\hline \multirow{2}{*}{ Nutrient } & \multirow{2}{*}{$\begin{array}{l}\text { Reference } \\
\text { values }\end{array}$} & \multicolumn{2}{|c|}{ Girls $(n=64)$} & \multicolumn{2}{|c|}{ Boys $(n=56)$} & \multicolumn{2}{|c|}{ All children $(n=120)$} & \multirow[t]{2}{*}{$P$} & \multicolumn{2}{|c|}{ Girls $(n=64)$} & \multicolumn{2}{|c|}{ Boys $(n=56)$} & \multicolumn{2}{|c|}{ All children $(n=120)$} \\
\hline & & Mean & SD & Mean & SD & Mean & SD & & Median & SE & Median & SE & Median & SE \\
\hline \multicolumn{15}{|c|}{ Vitamin A (retinol equivalent) } \\
\hline$(\mu \mathrm{g})$ & $300^{1}$ & 1088 & 650 & 1062 & 550 & 1076 & 603 & 0.701 & 984 & 81 & 875 & 74 & 952 & 55 \\
\hline ( $\mu \mathrm{g} / 1000$ kcal) & NA & 619 & 402 & 562 & 298 & 592 & 357 & 0.232 & 538 & 50 & 457 & 40 & 500 & 33 \\
\hline \multicolumn{15}{|l|}{ Retinol } \\
\hline$(\mu \mathrm{g})$ & NA & 505 & 566 & 489 & 233 & 498 & 441 & 0.303 & 411 & 71 & 433 & 31 & 430 & 40 \\
\hline ( $\mu \mathrm{g} / 1000$ kcal) & NA & 291 & 373 & 258 & 130 & 275 & 286 & 0.925 & 226 & 47 & 231 & 17 & 227 & 26 \\
\hline \multicolumn{15}{|l|}{ Beta-carotene } \\
\hline$(\mu \mathrm{g})$ & NA & 3496 & 2454 & 3435 & 2769 & 3467 & 2595 & 0.504 & 2934 & 307 & 2428 & 370 & 2835 & 237 \\
\hline ( $\mu \mathrm{g} / 1000$ kcal) & NA & 1964 & 1323 & 1824 & 1486 & 1899 & 1397 & 0.269 & 1634 & 165 & 1380 & 199 & 1535 & 128 \\
\hline \multicolumn{15}{|l|}{ Vitamin D } \\
\hline$(\mu \mathrm{g})$ & $10^{1}$ & 2.35 & 1.35 & 2.21 & 1.12 & 2.29 & 1.25 & 0.987 & 1.93 & 0.17 & 2.10 & 0.15 & 1.96 & 0.11 \\
\hline$(\mu \mathrm{g} / 1000 \mathrm{kcal})$ & NA & 1.33 & 0.75 & 1.17 & 0.62 & 1.25 & 0.70 & 0.333 & 1.12 & 0.09 & 1.06 & 0.08 & 1.08 & 0.06 \\
\hline \multicolumn{15}{|l|}{ Vitamin E } \\
\hline (mg) & $6^{2}$ & 7.23 & 2.59 & 7.10 & 2.31 & 7.17 & 2.45 & 0.788 & 6.97 & 0.32 & 6.94 & 0.31 & 6.95 & 0.22 \\
\hline (mg/1000 kcal) & NA & 4.10 & 1.51 & 3.72 & 1.02 & 3.92 & 1.31 & 0.197 & 3.94 & 0.19 & 3.45 & 0.14 & 3.79 & 0.12 \\
\hline \multicolumn{15}{|l|}{ Vitamin $B_{1}$} \\
\hline (mg) & $0.5^{1}$ & 0.999 & 0.331 & 1.016 & 0.371 & 1.007 & 0.348 & 0.879 & 0.948 & 0.041 & 0.954 & 0.050 & 0.949 & 0.032 \\
\hline (mg/1000 kcal) & NA & 0.565 & 0.177 & 0.536 & 0.198 & 0.551 & 0.187 & 0.352 & 0.524 & 0.022 & 0.492 & 0.027 & 0.513 & 0.017 \\
\hline \multicolumn{15}{|l|}{ Vitamin $B_{2}$} \\
\hline (mg) & $0.5^{1}$ & 1.693 & 0.468 & 1.668 & 0.492 & 1.681 & 0.478 & 0.636 & 1.654 & 0.059 & 1.672 & 0.066 & 1.659 & 0.044 \\
\hline (mg/1000 kcal) & NA & 0.958 & 0.258 & 0.880 & 0.247 & 0.922 & 0.255 & 0.071 & 0.937 & 0.032 & 0.865 & 0.033 & 0.910 & 0.023 \\
\hline \multicolumn{15}{|l|}{ Vitamin $B_{6}$} \\
\hline (mg) & $0.5^{1}$ & 1.51 & 0.36 & 1.50 & 0.37 & 1.51 & 0.36 & 0.986 & 1.49 & 0.04 & 1.45 & 0.05 & 1.48 & 0.03 \\
\hline (mg/1000 kcal) & NA & 0.86 & 0.20 & 0.80 & 0.18 & 0.83 & 0.19 & 0.075 & 0.83 & 0.02 & 0.78 & 0.02 & 0.80 & 0.02 \\
\hline \multicolumn{15}{|l|}{ Folic acid } \\
\hline$(\mu \mathrm{g})$ & $160^{1}$ & 201.3 & 43.6 & 202.9 & 39.1 & 202.0 & 41.4 & 0.925 & 196.9 & 5.4 & 198.1 & 5.2 & 197.5 & 3.8 \\
\hline ( $\mu \mathrm{g} / 1000 \mathrm{kcal})$ & NA & 114.2 & 25.4 & 107.0 & 15.2 & 110.8 & 21.5 & 0.049 & 110.3 & 3.2 & 103.5 & 2.0 & 107.0 & 2.0 \\
\hline \multicolumn{15}{|l|}{ Vitamin $B_{12}$} \\
\hline$(\mu \mathrm{g})$ & $1.0^{1}$ & 3.52 & 2.21 & 3.59 & 1.25 & 3.55 & 1.82 & 0.318 & 3.24 & 0.28 & 3.44 & 0.17 & 3.29 & 0.17 \\
\hline ( $\mathrm{gg} / 1000$ kcal) & NA & 2.02 & 1.45 & 1.89 & 0.65 & 1.96 & 1.14 & 0.713 & 1.77 & 0.18 & 1.66 & 0.09 & 1.76 & 0.10 \\
\hline
\end{tabular}


Table 1 Vitamin intakes in the studied 6-year-old children (Continued)

\begin{tabular}{|c|c|c|c|c|c|c|c|c|c|c|c|c|c|c|}
\hline \multicolumn{15}{|l|}{ Niacin } \\
\hline (mg) & $6^{1}$ & 12.30 & 3.31 & 12.24 & 3.15 & 12.27 & 3.23 & 0.875 & 11.42 & 0.41 & 11.43 & 0.42 & 11.43 & 0.29 \\
\hline (mg/1000 kcal) & NA & 7.01 & 1.93 & 6.47 & 1.56 & 6.76 & 1.78 & 0.094 & 6.85 & 0.24 & 6.14 & 0.21 & 6.36 & 0.16 \\
\hline \multicolumn{15}{|l|}{ Vitamin C } \\
\hline (mg) & $40^{1}$ & 77.9 & 36.6 & 66.9 & 31.0 & 72.8 & 34.4 & 0.051 & 73.0 & 4.6 & 59.8 & 4.1 & 65.5 & 3.1 \\
\hline (mg/1000 kcal) & NA & 43.9 & 20.3 & 35.3 & 16.3 & 39.9 & 18.9 & 0.003 & 40.7 & 2.5 & 32.6 & 2.2 & 35.7 & 1.7 \\
\hline
\end{tabular}

NA - not available; $P$ - significance.

EAR; ${ }^{2}$ Al. 
Table 2 The percentages of the studied 6-year-old children in the reference ranges for vitamin intakes

\begin{tabular}{|c|c|c|c|c|}
\hline \multirow[t]{2}{*}{ Nutrient } & $\begin{array}{l}\text { Girls } \\
(n=64)\end{array}$ & $\begin{array}{l}\text { Boys } \\
(n=56)\end{array}$ & $\begin{array}{l}\text { All children } \\
(n=120)\end{array}$ & $P$ \\
\hline & $\%$ & $\%$ & $\%$ & \\
\hline \multicolumn{5}{|c|}{ Vitamin A (retinol equivalent) } \\
\hline Below EAR & 0.0 & 0.0 & 0.0 & $\#$ \\
\hline \multicolumn{5}{|l|}{ Retinol } \\
\hline Above UL & 1.6 & 1.8 & 1.7 & 0.924 \\
\hline \multicolumn{5}{|l|}{ Vitamin D } \\
\hline Below EAR & 100.0 & 100.0 & 100.0 & $\#$ \\
\hline \multicolumn{5}{|l|}{ Vitamin E } \\
\hline Below Al & 34.4 & 41.1 & 37.5 & 0.450 \\
\hline Above UL & 0.0 & 0.0 & 0.0 & $\#$ \\
\hline \multicolumn{5}{|l|}{ Vitamin $B_{1}$} \\
\hline Below EAR & 1.6 & 0.0 & 0.8 & 0.350 \\
\hline \multicolumn{5}{|l|}{ Vitamin $B_{2}$} \\
\hline Below EAR & 0.0 & 0.0 & 0.0 & $\#$ \\
\hline \multicolumn{5}{|l|}{ Vitamin $B_{6}$} \\
\hline Below EAR & 0.0 & 0.0 & 0.0 & $\#$ \\
\hline Above UL & 0.0 & 0.0 & 0.0 & $\#$ \\
\hline \multicolumn{5}{|l|}{ Folic acid } \\
\hline Below EAR & 12.5 & 8.9 & 10.8 & 0.530 \\
\hline Above UL & 1.6 & 1.8 & 1.7 & 0.924 \\
\hline \multicolumn{5}{|l|}{ Vitamin $B_{12}$} \\
\hline Below EAR & 0.0 & 0.0 & 0.0 & $\#$ \\
\hline \multicolumn{5}{|l|}{ Niacin } \\
\hline Below EAR & 1.6 & 1.8 & 1.7 & 0.924 \\
\hline Above UL & 26.6 & 14.3 & 20.8 & 0.099 \\
\hline \multicolumn{5}{|l|}{ Vitamin C } \\
\hline Below EAR & 10.9 & 16.1 & 13.3 & 0.409 \\
\hline Above UL & 0.0 & 0.0 & 0.0 & $\#$ \\
\hline
\end{tabular}

\# - $P$ cannot be calculated when percentage is 0.0 or 100.0 .

increased risk of cardiovascular diseases, such as coronary heart disease and stroke [31,32]. This is of great importance to the studied children because of their excessive intake of saturated fatty acids and animal protein along with inadequate intake of polyunsaturated fatty acids, which pose the risk of developing cardiovascular diseases, as reported in the previous article [7]. Therefore, inadequate intakes of B vitamins would aggravate the risk of developing these diseases in the studied 6-year-olds. Additionally, the same effect would have inadequate intakes of antioxidant vitamins and so it is highly favourable that intakes of $\beta$-carotene and vitamins $\mathrm{E}$ and $\mathrm{C}$ pose low risk of inadequate intake in the studied children.

The only major concern in the studied 6-year-olds is low intake of vitamin $\mathrm{D}$ which implies high risk of inadequate intake. Similar or even lower intakes of vitamin D were observed in 4-10-year-old [10] and 7-year-old [30] British children, and in Spanish 6-9-year-old children [17]. Also, Belgian 4-6.5-year-olds [14] were characterised by lower intake of vitamin D compared to the studied 6-year-olds and almost all of them had intakes lower than Belgian recommendations. Such low intake of vitamin D is highly disconcerting because it may adversely affect the studied children's bones and teeth [33,34]. Moreover, studies imply that deficiency of this vitamin has negative impact on insulin resistance and $\beta$ cell function [35-37] increasing the risk of diabetes. Although vitamin D is synthesised as a result of exposure to solar ultraviolet-B irradiation [38], in Polish climatic conditions such low intake of vitamin $\mathrm{D}$ is unlikely to be compensated by cutaneous synthesis of this vitamin. It is highly surprising that the staff of preschools promoting health failed to spread the recommendation of eating fish 
Table 3 Mineral intakes in the studied 6-year-old children

\begin{tabular}{|c|c|c|c|c|c|c|c|c|c|c|c|c|c|c|}
\hline \multirow[t]{2}{*}{ Nutrient } & \multirow{2}{*}{$\begin{array}{l}\text { Reference } \\
\text { values }\end{array}$} & \multicolumn{2}{|l|}{$\begin{array}{l}\text { Girls } \\
(n=64)\end{array}$} & \multicolumn{2}{|l|}{$\begin{array}{l}\text { Boys } \\
(n=56)\end{array}$} & \multicolumn{2}{|c|}{$\begin{array}{l}\text { All children } \\
(n=120)\end{array}$} & \multirow[t]{2}{*}{$P$} & \multicolumn{2}{|l|}{$\begin{array}{l}\text { Girls } \\
(n=64)\end{array}$} & \multicolumn{2}{|l|}{$\begin{array}{l}\text { Boys } \\
(n=56)\end{array}$} & \multicolumn{2}{|c|}{$\begin{array}{l}\text { All children } \\
(n=120)\end{array}$} \\
\hline & & Mean & SD & Mean & SD & Mean & SD & & Median & SE & Median & SE & Median & SE \\
\hline \multicolumn{15}{|l|}{ Calcium } \\
\hline (mg) & $800^{1}$ & 673 & 201 & 712 & 227 & 691 & 213 & 0.327 & 640 & 25 & 663 & 30 & 652 & 19 \\
\hline (mg/1000 kcal) & NA & 378 & 96 & 374 & 99 & 376 & 97 & 0.799 & 371 & 12 & 374 & 13 & 371 & 9 \\
\hline \multicolumn{15}{|l|}{ Phosphorus } \\
\hline (mg) & $410^{1}$ & 992 & 199 & 1050 & 227 & 1019 & 213 & 0.201 & 971 & 25 & 1021 & 30 & 994 & 19 \\
\hline (mg/1000 kcal) & NA & 560 & 84 & 553 & 86 & 557 & 84 & 0.866 & 553 & 10 & 548 & 11 & 551 & 8 \\
\hline \multicolumn{15}{|l|}{ Magnesium } \\
\hline (mg) & $110^{1}$ & 218 & 42 & 228 & 47 & 223 & 45 & 0.468 & 217 & 5 & 217 & 6 & 217 & 4 \\
\hline (mg/1000 kcal) & NA & 123 & 18 & 120 & 19 & 122 & 18 & 0.386 & 124 & 2 & 123 & 3 & 123 & 2 \\
\hline \multicolumn{15}{|l|}{ Sodium } \\
\hline (mg) & $1000^{2}$ & 2876 & 557 & 3194 & 650 & 3024 & 620 & 0.023 & 2960 & 70 & 3125 & 87 & 2989 & 57 \\
\hline (mg/1000 kcal) & NA & 1634 & 299 & 1685 & 265 & 1658 & 284 & 0.326 & 1630 & 37 & 1656 & 35 & 1645 & 26 \\
\hline \multicolumn{15}{|l|}{ Potassium } \\
\hline (mg) & $3100^{2}$ & 2450 & 471 & 2511 & 498 & 2478 & 482 & 0.493 & 2491 & 59 & 2453 & 66 & 2468 & 44 \\
\hline (mg/1000 kcal) & NA & 1383 & 199 & 1326 & 212 & 1356 & 206 & 0.128 & 1377 & 25 & 1342 & 28 & 1366 & 19 \\
\hline \multicolumn{15}{|l|}{ Iron } \\
\hline (mg) & $4^{1}$ & 9.0 & 2.0 & 9.4 & 2.3 & 9.2 & 2.1 & 0.315 & 8.8 & 0.2 & 9.0 & 0.3 & 8.9 & 0.2 \\
\hline (mg/1000 kcal) & NA & 5.1 & 1.0 & 5.0 & 1.0 & 5.0 & 1.0 & 0.446 & 4.8 & 0.1 & 4.7 & 0.1 & 4.8 & 0.1 \\
\hline \multicolumn{15}{|l|}{ Zinc } \\
\hline (mg) & $4^{1}$ & 6.7 & 1.3 & 7.2 & 1.3 & 6.9 & 1.3 & 0.041 & 6.6 & 0.2 & 7.1 & 0.2 & 6.8 & 0.1 \\
\hline (mg/1000 kcal) & NA & 3.8 & 0.5 & 3.8 & 0.5 & 3.8 & 0.5 & 0.290 & 3.7 & 0.1 & 3.9 & 0.1 & 3.8 & 0.0 \\
\hline \multicolumn{15}{|l|}{ Copper } \\
\hline (mg) & $0.3^{1}$ & 0.88 & 0.18 & 0.93 & 0.19 & 0.90 & 0.19 & 0.134 & 0.86 & 0.02 & 0.91 & 0.03 & 0.87 & 0.02 \\
\hline (mg/1000 kcal) & NA & 0.50 & 0.08 & 0.49 & 0.08 & 0.49 & 0.08 & 0.704 & 0.49 & 0.01 & 0.48 & 0.01 & 0.49 & 0.01 \\
\hline \multicolumn{15}{|l|}{ Manganese } \\
\hline (mg) & $1.5^{2}$ & 3.00 & 0.79 & 3.23 & 0.77 & 3.11 & 0.79 & 0.106 & 2.90 & 0.10 & 3.17 & 0.10 & 3.09 & 0.07 \\
\hline (mg/1000 kcal) & NA & 1.70 & 0.41 & 1.71 & 0.38 & 1.70 & 0.40 & 0.829 & 1.69 & 0.05 & 1.62 & 0.05 & 1.66 & 0.04 \\
\hline \multicolumn{15}{|l|}{ lodine } \\
\hline$(\mu \mathrm{g})$ & $65^{1}$ & 129.3 & 31.9 & 138.4 & 35.7 & 133.5 & 33.9 & 0.144 & 130.5 & 4.0 & 136.0 & 4.8 & 132.3 & 3.1 \\
\hline$(\mu \mathrm{g} / 1000 \mathrm{kcal})$ & NA & 73.8 & 19.6 & 73.4 & 18.4 & 73.6 & 19.0 & 0.925 & 71.5 & 2.4 & 72.2 & 2.5 & 71.7 & 1.7 \\
\hline
\end{tabular}

NA - not available; $P$ - significance.

${ }^{1} \mathrm{EAR} ;{ }^{2} \mathrm{Al}$.

frequently which would prevent inadequate vitamin D intakes in the studied children.

In the previous studies on vitamin intakes, 6-year-old children were included in groups of children of various age ranges [10-19], therefore, direct comparison to other studies is not possible. Only nutrient density may be compared directly because it is not dependent on total energy intake. In Cretan 5.7-7.6-year-old children [18] nutrient densities were higher than in the studied 6-year-olds for six out of nine analysed vitamins, that is for vitamin $B_{1}, B_{2}, B_{6}$, folic acid, niacin and vitamin C [18]. Serra-Majem et al. [17] and Glynn et al. [30] also analysed nutrient densities but in the former study the amounts of vitamins were given per $1000 \mathrm{~kJ}$ of energy intake while in the latter study only statistically significant differences according to gender were analysed and no values were presented.

Although vitamin intakes cannot be compared directly to other studies, it is interesting to note that intake of vitamin $\mathrm{A}$ in the studied 6-year-old children was much higher than in British 4-6-year-olds [13], but also much higher than in older groups of children: 4-10-year-old [10] and 7-year-old [30] British children, 6-7-year-old [15,16] and 6-9-year-old [17] Spanish children, and even in the United States 6-11year-olds [12]. In Polish 4-6-year-olds [19], intake of vitamin 
A was also lower in comparison to the studied 6-year-old children, but it was higher than in children from other countries irrespective of age. In comparison to those studies in which intakes of retinol $[10,13,19,30]$ and $\beta$-carotene $[13,19,30]$ were analysed, intakes of these nutrients were also the highest in the studied children as well as in the previously studied Polish 4-6-year-olds [19]. This high intake of vitamin $\mathrm{A}$ in the studied 6-year-old children may be explained by high consumption of carrot juice which is very popular in Poland, especially among children and adolescents. There are many brands of carrot juice in Poland addressed particularly to the youngest consumers. Moreover, the studied children attended preschools promoting health where the staff tried to implement the habit of eating vegetables. The region where the studied children lived is not affluent and carrot which is not an expensive vegetable was often consumed by the children at preschool. The other habit which surely increased vitamin A intake is daily use of butter which is in Poland the most popular fat to spread on sandwiches.

In the previous studies, which reported vitamin intakes in children of similar age to the studied 6-year-olds, the populations of children were divided according to gender [10,12-14,17-19,30], except for the Spanish 6-7-year-olds $[15,16]$ whose intakes were analysed according to the city where the children lived. However, statistically significant differences according to gender were tested only in two of those studies $[14,30]$.

It was expected to find many statistically significant differences in vitamin intakes between the studied girls and boys. However, it turned out not to be true in the studied children. Glynn et al. [30] found statistically significant differences in intakes of five vitamins in English 7-year-olds, while Huybrechts and De Henauw [14] found significant differences in intakes of four vitamins in Belgian 4-6.5-year-olds.

In the previous studies, vitamin intakes were usually reported to be higher in boys than in girls $[10,12-14,17]$. Only in 7-year-old English children [30], girls were characterised by higher intake of vitamin $A$, retinol and $\beta$ carotene, and in 4-6-year-old Polish children [19] girls were characterised by higher intakes of vitamin $A, \beta-$ carotene, vitamin $B_{2}$, niacin and vitamin $C$. However, these differences were minor and statistically insignificant. Quite opposite, Huybrechts and De Henauw [14] found statistically significantly lower intakes of vitamins $D, B_{1}, B_{2}$ and $C$ in Belgian 4-6.5-year-old girls in comparison to their male peers, while Glynn et al. [30] in the group of English 7-year-olds found statistically significantly lower intakes of vitamins $B_{1}, B_{2}, B_{6}$, niacin and folic acid in females in comparison to males.

Among the previous studies on vitamin intakes in children of similar age to the studied 6-year-olds, nutrient densities for vitamins were analysed only in three of them $[17,18,30]$. Unlike in the studied 6-year-olds, nutrient densities for vitamins were not always higher in girls. Glynn et al. [30] found higher nutrient densities in English 7 -year-old girls only for vitamin $A$, retinol and $\beta$-carotene, however, all these differences were statistically significant. Smpokos et al. [18] reported higher nutrient densities in Cretan 5.7-7.6-year-old girls for as many as six out of nine analysed vitamins but Serra-Majem et al. [17] reported higher nutrient densities in 6-9-year-old Spanish girls for only three out of ten vitamins. However, neither Smpokos et al. [18] nor Serra-Majem et al. [17] tested statistically significant differences according to gender.

\section{Mineral intakes}

It is surprising that the studied 6-year-old children are at risk of inadequate calcium intake. The importance of drinking milk to children's bone health has been spread throughout the Polish society for many years and even television has broadcast a series of spots promoting the habit of daily milk drinking. Also, the producers of dairy products use this recommendation in the commercials. Moreover, the children attended preschools promoting health and therefore it would seem obvious that basic nutritional guidelines should be promoted by the preschool staff. Most of the preschool staff and the studied children's parents knew that high intake of milk and dairy products in childhood prevents osteoporosis $[39,40]$ and that milk and dairy products are rich sources of calcium $[41,42]$. The adverse effect of inadequate calcium intake may be aggravated by the abovementioned inadequate vitamin $\mathrm{D}$ intake and by quite high phosphorus intake. Although the studied children did not exceed the UL, phosphorus intake was much higher than calcium intake. This may disturb the proportion of calcium to phosphorus which should be about $1.2: 1$ in children's diet according to the Polish recommendations [43].

Another adverse characteristic of the studied 6-yearolds' diets was excessive intake of sodium found in all of the studied children. Exceeding sodium UL poses the risk of developing hypertension, particularly when taking into account quite low potassium intake. Although EAR for potassium has not been established, mean intake below AI shows the need to increase intake of this mineral to prevent hypertension in the studied 6-year-olds. It is unexpected that the preschool staff failed to convince the parents of the necessity to reduce salt intake and did not implement this simple rule during the preparation of preschool meals. It is even more surprising when taking into account that the majority of both the preschool staff and the studied children's parents knew that high salt intake increases the risk of hypertension $[39,40]$. These findings confirm the necessity to implement programme aimed at reducing salt intake as proposed in the previous article [44]. 
Table 4 The percentages of the studied 6-year-old children in the reference ranges for mineral intakes

\begin{tabular}{|c|c|c|c|c|}
\hline \multirow[t]{2}{*}{ Nutrient } & $\begin{array}{l}\text { Girls } \\
(n=64)\end{array}$ & $\begin{array}{l}\text { Boys } \\
(n=56)\end{array}$ & $\begin{array}{l}\text { All children } \\
(n=120)\end{array}$ & \multirow[t]{2}{*}{$P$} \\
\hline & $\%$ & $\%$ & $\%$ & \\
\hline \multicolumn{5}{|l|}{ Calcium } \\
\hline Below EAR & 76.6 & 66.1 & 71.7 & 0.203 \\
\hline Above UL & 0.0 & 0.0 & 0.0 & $\#$ \\
\hline \multicolumn{5}{|l|}{ Phosphorus } \\
\hline Below EAR & 0.0 & 0.0 & 0.0 & $\#$ \\
\hline Above UL & 0.0 & 0.0 & 0.0 & $\#$ \\
\hline \multicolumn{5}{|l|}{ Magnesium } \\
\hline Below EAR & 0.0 & 0.0 & 0.0 & $\#$ \\
\hline \multicolumn{5}{|l|}{ Sodium } \\
\hline Below Al & 0.0 & 0.0 & 0.0 & $\#$ \\
\hline Above UL & 100.0 & 100.0 & 100.0 & $\#$ \\
\hline \multicolumn{5}{|l|}{ Potassium } \\
\hline Below Al & 92.2 & 83.9 & 88.3 & 0.160 \\
\hline \multicolumn{5}{|l|}{ Iron } \\
\hline Below EAR & 0.0 & 0.0 & 0.0 & $\#$ \\
\hline Above UL & 0.0 & 0.0 & 0.0 & $\#$ \\
\hline \multicolumn{5}{|l|}{ Zinc } \\
\hline Below EAR & 1.6 & 0.0 & 0.8 & 0.350 \\
\hline Above UL & 3.1 & 5.4 & 4.2 & 0.543 \\
\hline \multicolumn{5}{|l|}{ Copper } \\
\hline Below EAR & 0.0 & 0.0 & 0.0 & $\#$ \\
\hline Above UL & 0.0 & 0.0 & 0.0 & $\#$ \\
\hline \multicolumn{5}{|l|}{ Manganese } \\
\hline Below Al & 0.0 & 0.0 & 0.0 & $\#$ \\
\hline Above UL & 46.9 & 57.1 & 51.7 & 0.261 \\
\hline \multicolumn{5}{|l|}{ lodine } \\
\hline Below EAR & 0.0 & 0.0 & 0.0 & $\#$ \\
\hline Above UL & 0.0 & 0.0 & 0.0 & \# \\
\hline
\end{tabular}

$P$ - significance;

\# - $P$ cannot be calculated when percentage is 0.0 or 100.0 .

It is also disconcerting that manganese intake exceeded UL in about a half of the studied children. However, bioavailability of this mineral from food sources have been found to be affected by other dietary factors [23], such as phytate which reduces the efficiency of absorption of manganese [45]. Therefore, blood manganese concentration should be measured in the studied children to conclude whether manganese intake is excessive.

Similarly to vitamin intakes, also mineral intakes cannot be compared directly to the results of other studies because of the age differences among the studied populations of children. However, it is important to note that sodium intake in the studied children was higher than in 4-6-year-old Polish children [19] and much higher than in 4-6-year-old British children [13] and 4-6.5-year-old Belgian children
[14]. Moreover, it was higher even than in older children: British 7-year-olds [30], as well as 6-7-year-old [15,16] and 6-9-year-old [17] Spanish children. Nutrient densities for calcium, potassium and iron in the studied children were lower than nutrient densities for these minerals in Cretan 5.7-7.6-year-olds [18]. However, nutrient density for sodium in the studied 6-year-olds was much higher than in Cretan 5.7-7.6-year-olds [18]. Nutrient densities for other minerals were not analysed by Smpokos et al. [18].

Contrary to expectations and similarly to vitamin intakes, there were statistically significant gender differences in the intakes of only two minerals in the studied 6-yearolds. Among those studies in which differences in mineral intakes were tested according to gender, only two of them reported statistically significant differences $[14,30]$. 
Higher intakes of all the analysed minerals in the studied 6-year-old boys compared to their female peers, were also observed in all of the previously studied children $[10,11,13,14,17,19,30]$. Only calcium intake in Polish 4-6-year-old boys [19] and magnesium intake in 4-6.5-year-old Belgian boys [14] were not higher than in their female peers. Moreover, Huybrechts and De Henauw [14] and Glynn et al. [30] reported these differences to be statistically significant, except for selenium intake in 7-year-old English boys [30].

Higher nutrient densities for most of the analysed minerals in the studied 6-year-old girls compared to their male peers were not as noticeable as in the case of vitamins. Smpokos et al. [18] reported higher nutrient densities for three out of four minerals in Cretan 5.7-7.6-year-old girls but Serra-Majem et al. [17] - only for two out of six minerals in Spanish 6-9-year-old girls.

\section{Conclusions}

In conclusion, inadequate intakes of vitamin $\mathrm{D}$, calcium and potassium in the studied 6-year-olds along with excessive sodium intake are the risk factors for developing osteoporosis and hypertension. To prevent these diseases in the studied children, educational programmes for both preschool staff and parents should be worked out and implemented.

\section{Competing interests}

The authors declare that they have no competing interests.

\section{Authors' contributions}

SM and WC conceptualized and designed the study. SM searched for the literature, extracted and analysed data, and drafted the initial manuscript. WC analysed data and critically reviewed the initial manuscript. SM and WC approved the final manuscript as submitted.

\section{Acknowledgements}

Financial support was received from the Polish Ministry of Science and Higher Education.

Received: 8 September 2014 Accepted: 8 December 2014

Published online: 24 December 2014

\section{References}

1. St-Onge MP, Keller KL, Heymsfield SB: Changes in childhood food consumption patterns: a cause for concern in light of increasing body weights. Am J Clin Nutr 2003, 78:1068-1073.

2. Gibson SA: Non-milk extrinsic sugars in the diets of pre-school children: association with intakes of micronutrients, energy, fat and NSP. Br J Nutr 1997, 78:367-378.

3. Alexy U, Sichert-Hellert W, Kersting M: Associations between intake of added sugars and intakes of nutrients and food groups in the diets of German children and adolescents. Br J Nutr 2003, 90:441-447.

4. Øverby NC, Lillegaard ITL, Johansson L, Andersen LF: High intake of added sugar among Norwegian children and adolescents. Public Health Nutr 2004, 7(2):285-293.

5. Kranz S, Smiciklas-Wright H, Siega-Riz AM, Mitchell D: Adverse effect of high added sugar consumption on dietary intake in American preschoolers. J Pediatr 2005, 146:105-111.

6. Merkiel S, Chalcarz W: Nutrition in preschool age: Part 1. Importance, reference values, methods of research and their application. Review. New Med (Wars) 2007, 11:68-73.
7. Merkiel S: Dietary intake in 6-year-old children from southern Poland: part 1 - energy and macronutrient intakes. BMC Pediatrics 2014, 14:197.

8. Bryan J, Osendarp S, Hughes D, Calvaresi E, Baghurst K, Van Klinken JW: Nutrients for cognitive development in school-aged children. Nutr Rev 2004, 62:295-306.

9. Hulthén L: Iron deficiency and cognition. Scand J Nutr 2003, 47:152-156.

10. Bates B, Lennox A, Prentice A, Bates C, Page P, Nicholson S, Swan G: National diet and nutrition survey. Results from Years 1, 2, 3 and 4 (combined) of the rolling programme (2008/2009 - 2011/2012) [https:// www.gov.uk/government/publications/national-diet-and-nutrition-surveyresults-from-years-1-to-4-combined-of-the-rolling-programme-for-2008-and2009-to-2011-and-2012]. Accessed: 21 ${ }^{\text {st }}$ July 2014.

11. Ervin RB, Wang CY, Wright JD, Kennedy-Stephenson J: Dietary intake of selected minerals for the United States population: 1999-2000. Advance data from vital and health statistics; no. 341. Hyattsville, Maryland: National Center for Health Statistics; 2004.

12. Ervin RB, Wright JD, Wang CY, Kennedy-Stephenson J: Dietary intake of selected vitamins for the United States Population: 1999-2000. Advance data from vital and health statistics; no 339. Hyattsville, Maryland: National Center for Health Statistics; 2004.

13. Great Britain Office for National Statistics Social Survey Division: National Diet and Nutrition Survey: young people aged 4 to 18 years. Volume 1: Report of the diet and nutrition survey. London: Stationery Office; 2000.

14. Huybrechts I, De Henauw S: Energy and nutrient intakes by pre-school children in Flanders-Belgium. Br J Nutr 2007, 98:600-610.

15. Rodríguez-Artalejo F, Garcés C, Gorgojo L, López García E, Martín Moreno JM, Benavente M, Del Barrio JL, Rubio R, Ortega H, Fernández O, De Oya M: Dietary patterns among children aged 6-7 y in four Spanish cities with widely differing cardiovascular mortality. Eur J Clin Nutr 2002, 56:141-148.

16. Rodríguez-Artalejo F, López García E, Gorgojo L, Garcés C, Royo MA, Martín Moreno JM, Benavente M, Macías A, De Oya M: Consumption of bakery products, sweetened soft drinks and yogurt among children aged 6-7 years: association with nutrient intake and overall diet quality. Br J Nutr 2003, 89:419-428.

17. Serra-Majem L, Ribas-Barba L, Pérez-Rodrigo C, Aranceta Bartrina J: Nutrient adequacy in Spanish children and adolescents. Br J Nutr 2006, 96(Suppl 1):S49-S57.

18. Smpokos EA, Linardakis M, Papadaki A, Theodorou AS, Havenetidis K, Kafatos A: Differences in energy and nutrient-intake among Greek children between 1992/93 and 2006/07. J Hum Nutr Diet 2013: doi:10.1111/jhn.12122

19. Szponar L, Sekuła W, Rychlik E, Ołtarzewski M, Figurska K: Badania indywidualnego spożycia żywności i stanu odżywienia w gospodarstwach domowych, in Polish. (Research on individual food intake and nutritional status in households.). Warszawa: Instytut Żywności i Żywienia; 2003.

20. Merkiel S, Chalcarz W: Challenges of dietary intake assessment in preschool children - conclusions from a dietary intervention study on Polish preschoolers. New Med (Wars) 2014, 18(2):47-51.

21. Jarosz M: Normy żywienia dla populacji polskiej - nowelizacja, in Polish. (Dietary reference intakes for the Polish population - amendment). Warszawa: Instytut Żywności i Żywienia; 2012.

22. Food and Nutrition Board of the Institute of Medicine: Dietary Reference Intakes for calcium and vitamin D. Washington DC: the National Academies Press; 2011.

23. Food and Nutrition Board of the Institute of Medicine: Dietary Reference Intakes for vitamin A, vitamin K, arsenic, boron, chromium, copper, iodine, iron, manganese, molybdenum, nickel, silicon, vanadium and zinc. Washington DC: the National Academies Press; 2001.

24. Scienfitic Committee on Food, Scientific Panel of Dietetic Products, Nutrition and Allergies: Tolerable upper intake levels for vitamins and minerals. Brussels: European Food Safety Authority (EFSA); 2006.

25. Food and Nutrition Board of the Institute of Medicine: Dietary Reference Intakes for calcium, phosphorus, magnesium, vitamin D and fluoride. Washington DC: the National Academies Press; 1997.

26. Food and Nutrition Board of the Institute of Medicine: Dietary Reference Intakes for vitamin C, vitamin E, selenium and carotenoids. Washington DC: the National Academies Press; 2000.

27. Food and Nutrition Board of the Institute of Medicine: Dietary Reference Intakes for thiamin, riboflavin, niacin, vitamin $B_{6}$, folate, vitamin $B_{12}$, panthotenic acid, biotin and choline. Washington DC: the National Academies Press; 1998.

28. Food and Nutrition Board of the Institute of Medicine: Dietary Reference Intakes. Applications in dietary assessment. Washington DC: the National Academies Press; 2003. 
29. Serdula MK, Alexander MP, Scanlon KS, Bowman BA: What are preschool children eating? A review of dietary assessment. Annu Rev Nutr 2001, 21:475-498.

30. Glynn L, Emmett P, Rogers I: Food and nutrient intakes of a population sample of 7-year-old children in the south-west of England in 19992000 - what difference does gender make? J Hum Nutr Diet 2005, 18:7-19.

31. Wang ZM, Zhou B, Nie ZL, Gao W, Wang YS, Zhao H, Zhu J, Yan JJ, Yang ZJ, Wang LS: Folate and risk of coronary heart disease: a meta-analysis of prospective studies. Nutr Metab Cardiovasc Dis 2012, 22:890-899.

32. Singh M: Role of micronutrients for physical growth and mental development. Indian J Pediatr 2004, 71:59-62.

33. Hujoel PP: Vitamin D and dental caries in controlled clinical trials: systematic review and meta-analysis. Nutr Rev 2013, 71:88-97.

34. Winzenberg $\mathrm{T}$, Jones $\mathrm{G}$ : Vitamin $\mathrm{D}$ and bone health in childhood and adolescence. Calcif Tissue Int 2013, 92:140-150.

35. Chiu KC, Chu A, Go VLW, Saad MF: Hypovitaminosis D is associated with insulin resistance and $\beta$ cell dysfunction. Am J Clin Nutr 2004, 79:820-825.

36. Sharifi F, Mousavinasab N, Mellati AA: Defining a cutoff point for vitamin D deficiency based on insulin resistance in children. Diabetes Metab Syndr 2013, 7:210-213.

37. Sung CC, Liao MT, Lu KC, Wu CC: Role of vitamin D in insulin resistance. J Biomed Biotechnol 2012, 2012:634195.

38. Grant WB, Holick MF: Benefits and requirements of vitamin D for optimal health: a review. Altern Med Rev 2005, 10:94-111.

39. Chalcarz W, Merkiel S: Wiedza żywieniowa rodziców dzieci przedszkolnych z Nowego Sącza i okolic. 2. Żywienie w profilaktyce chorób dietozależnych, in Polish. (Nutritional knowledge of parents of preschool children from Nowy Sącz and the vicinity. 2. Nutritional prevention of diet-related diseases.) Żyw Człow Metab 2009, 36:390-395.

40. Merkiel S, Chalcarz W: Nutritional knowledge of the preschool staff from Nowy Sącz and the vicinity. Part 2. Nutritional prevention of diet-related diseases. New Med (Wars) 2010, 14:49-52.

41. Chalcarz W, Merkiel S: Nutritional knowledge of the preschool staff from Nowy Sącz and the vicinity. Part 3. Rich sources of vitamins and minerals. New Med (Wars) 2010, 14:79-83.

42. Merkiel S, Chalcarz W: Wiedza żywieniowa rodziców dzieci przedszkolnych z Nowego Sącza i okolic. Część 3. Bogate źródła składników mineralnych i witamin, in Polish. (Nutritional knowledge of parents of preschool children from Nowy Sącz and the vicinity. 3. Rich sources of minerals and vitamins.) Nowa Pediatria 2010, 14:15-20

43. Jarosz M, Bułhak-Jachymczyk B: Normy żywienia człowieka. Podstawy prewencji otyłości i chorób niezakaźnych, in Polish. (Dietary reference intakes. The basis for the prevention of obesity and non-communicable diseases.). Warszawa: Wydawnictwo Lekarskie PZWL; 2008.

44. Merkiel S, Chalcarz W: Modifying salt intake to prevent hypertension. New Med (Wars) 2006, 9:30-34; erratum: New Med (Wars) 2006, 9:87.

45. Davidsson L, Almgren A, Juillerat MA, Hurrell RF: Manganese absorption in humans: the effect of phytic acid and ascorbic acid in soy formula. Am J Clin Nutr 1995, 62:984-987.

\section{Submit your next manuscript to BioMed Central and take full advantage of:}

- Convenient online submission

- Thorough peer review

- No space constraints or color figure charges

- Immediate publication on acceptance

- Inclusion in PubMed, CAS, Scopus and Google Scholar

- Research which is freely available for redistribution 